\title{
The Influence of Side-Curtain Color on Broiler Chick Behavior

\section{-Author(s)}

Vercellino $R$ do $A^{1}$

Moura DJ de ${ }^{1}$

Nääs I de $A$

Maia AP de $A^{1}$

Medeiros BBL'

Salgado DDA

Carvalho TRM de ${ }^{1}$

\section{ABSTRACT}

Brazilian poultry production is prospering, and negative-pressure broiler houses are increasingly used to improve environmental control. One important issue is the color of the side curtains used in such houses due to the influence of colors on broiler behavior. This study aimed at evaluating the influence of different curtain color on the welfare of 7-day-old broilers, considering luminosity and other environmental parameters. Chicks were housed in three different negative-pressure broiler houses either with black (T1), blue (T2), or yellow (T3) side curtains. House environment (luminosity, dry-bulb temperature, air relative humidity, air velocity, and gas emissions) and the behavior of chicks on day 7 after housing were evaluated in three consecutive flocks in the morning and in the afternoon. Data were submitted to multivariate analysis, Kruskal-Wallis' test, and Pearson's correlation test. Luminosity and ITU were influenced by curtain color, and some of the evaluated behaviors were associated with luminosity or other environmental parameter.

\section{INTRODUCTION}

In Brazil, the poultry industry applies modern technologies more than any other animal production activity (Lima et al., 2011). Modern broiler genetic strains have high performance genetic potential; however, proper conditions should be provided to allow birds to fully express this potential and to profit from their better productivity. One essential requirement is proper environmental control. Negative-pressure broiler houses provide a better environment and therefore are increasingly used.

In commercial poultry production, the color of the curtains used to close the sides of the conventional poultry houses has been discussed lately, particularly relative to the light intensity they allow inside. Poultry are more sensitive to environmental luminosity than humans (Lewis \& Morris, 2000; Prescott \& Wathes, 2001). However, the behavior of poultry is influenced by environmental factors other than luminosity (Dawkins, 1999; Ferrante et al., 2001), and understanding the effect of the environment on behavior allows identifying, quantifying, and characterizing thermal comfort and welfare conditions (Pereira et al., 2007). According to SCAHAW (2000), behavior is the leading means animals have to express their physical and mental states. Some researchers (Payne, 1967; Sturkie, 1967; Pereira et al., 2005; Silva et al., 2006; Salgado et al., 2007; Weeks \& Nicol, 2006; Alvino et al., 2009) mention that deviations or restriction of behaviors expressing physical activity (spreading wings, running, lying, standing, stretching, etc.), drinking and feeding, as well of the natural behavior of poultry (pecking, dust bathing, preening) may be considered stress indicators. 
The absence or presence of these behavior suggests poultry welfare status. In broilers, the first two weeks of life are the most critical, as management mistakes will have a strong impact on their final performance (Butcher \& Nilipour, 2002). According to Blockhuis \& Wiepkema (1998), many welfare problems observed in adult poultry result from problems in the rearing environment during the first week of life.

The objective of this study was to evaluate the behavior of seven-day-old broiler chicks reared in poultry houses with side curtains of different colors in order to determine which provides the best welfare conditions.

\section{MATERIALS AND METHODS}

The experiment was carried out in three commercial broiler houses. Two were located in the municipality of Tietê, SP (latitude $23^{\circ} 06^{\prime} 07^{\prime \prime} \mathrm{S}$, longitude $47^{\circ}$ $42^{\prime} 53^{\prime \prime} \mathrm{O}$, altitude $508 \mathrm{~m}$ ) and other located in Cerquilho, SP (latitude $23^{\circ} 09^{\prime} 54^{\prime \prime} \mathrm{S}$, longitude $47^{\circ}$ 44' 37" O, altitude 595 m), all in Brazil. The climate of these two municipalities is classified as Cwa (wet temperate climate, with dry winters and hot summers), according to Köppen's climate classification (1936). The experiment was carried out between March and August, 2011, totaling three flocks evaluated per broiler house.

\section{Broiler house characteristics}

The three evaluated houses were $150 \mathrm{~m}$ long, $14 \mathrm{~m}$ wide, and $3 \mathrm{~m}$ high, and built in the east-west direction. The houses were equipped with negativepressure ventilation and automatic feeding, drinking, and brooding systems. All houses had concrete floors, which were covered with wood-shavings litter in Tietê (rearing density of 14.7 birds $\mathrm{m}^{-2}$ ) and with sawdust in Cerquilho (rearing density of 14.5 birds $\mathrm{m}^{-2}$ ).

Treatments consisted of black side curtains (dark house, T1); blue side curtains (blue house, T2), or yellow side curtains (T3). T1 and T3 houses were located on the same farm, at the municipality of Tietê, whereas T2 house was located at the municipality of Cerquilho.

\section{Experimental procedures}

Behavior was monitored when broilers were seven days of age through a video camera (Sony ${ }^{\circledR}$, model SR68) placed on a tripod located at the center of the brooding circle in an angle that allowed recording the birds (Figure 1).

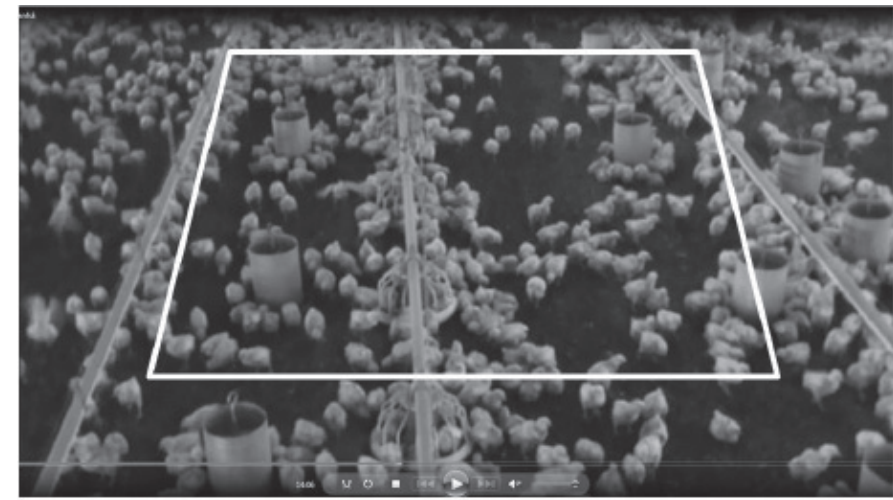

Figure 1 - Diagram of the area used for the behavioral analysis in all treatments.

Bird behavior was recorded in the morning and in the afternoon for 15 minutes, according to the methodology proposed by Bizeray et al. (2002). The following environmental parameters were collected at bird height and at the same location and time of behavior recording: luminosity $(\mathrm{L}$, in $\mathrm{Ix})$, dry bulb temperature $\left(\mathrm{DBT}\right.$, in $\left.{ }^{\circ} \mathrm{C}\right)$, air relative humidity $(\mathrm{RH}$, in $\%)$, air velocity $\left(\mathrm{AV}\right.$, in $\left.\mathrm{ms}^{-1}\right)$, ammonia concentration $\left(\mathrm{NH}_{3^{\prime}}\right.$ in $\left.\mathrm{ppm}\right)$ and carbon dioxide concentration $\left(\mathrm{CO}_{2}\right.$, in $\left.\mathrm{ppm}\right)$. Luminosity and relative humidity were measured using a digital multifunctional device (Instrutherm ${ }^{\circledR}$, model THDL-400), temperature and air velocity were collected using a thermo-anemometer (Extech ${ }^{\circledR}$, model 407123), and $\mathrm{NH}_{3}$ and $\mathrm{CO}_{2}$ a gas detectors (BW ${ }^{\circledR}$ Technologies, model GasAlert Micro5 IR). External temperature (DBT_EXT, in ${ }^{\circ} \mathrm{C}$ ) and relative humidity (RH_EXT, in \%) were recorded using a mini data logger (Onset $\circledast$ ).

Using dry bulb temperature and relative humidity data, the temperature and humidity index (THI) was calculated according to equation 1, proposed by Thom (1959). Values between 64 and 74 are considered as "comfortable"; between 74 and 78, "warning"; and higher than 78, "dangerous".

$\mathrm{THI}=\mathrm{DBT}+0.36 \mathrm{Tdp}+41.5$

where

THI - temperature and humidity index;

DBT - dry bulb temperature, in ${ }^{\circ} \mathrm{C}$; and

$\mathrm{Tdp}$ - dew point temperature, in ${ }^{\circ} \mathrm{C}$.

An ethogram, based on Campos (2000), Pereira (2005), and Neves et al. (2005) was adopted (Table 1).

Behavioral data were analyzed according the method of instantaneous scanning proposed by Altmann (1974) and used by several authors in different animal behavior studies (Ítavo et al., 2008; Albuquerque \& Codenotti, 2006; Passos \& Alho, 
Vercellino R do A, Moura DJ de,

Nääs I de A, Maia AP de A,

Medeiros BBL, Salgado DDA,

Carvalho TRM de

2001). In each recording, birds were randomly selected and the frequency of each behavior displayed during each recording was calculated (Table 1).

Table 1 - Bird ethogram.

\begin{tabular}{|c|c|}
\hline BEHAVIOR & DESCRIPTION \\
\hline $\begin{array}{l}\text { Wing } \\
\text { flapping }\end{array}$ & Movement in which the birds flaps both wings \\
\hline $\begin{array}{l}\text { Feather } \\
\text { ruffling }\end{array}$ & Birds ruffle all their feathers \\
\hline $\begin{array}{l}\text { Litter } \\
\text { pecking }\end{array}$ & Birds peck the litter with their beak \\
\hline Running & $\begin{array}{l}\text { bird moves between two points faster than } \\
\text { normally observed }\end{array}$ \\
\hline Lying & the bird remains sitting or lying on the litter \\
\hline Stretching & $\begin{array}{l}\text { The bird stretches the wing and the leg of the same } \\
\text { side of the body }\end{array}$ \\
\hline Preening & The bird cleans and aligns its feather using its beak \\
\hline Dust bathing & The bird throws litter substrate on its body \\
\hline Eating & $\begin{array}{l}\text { The bird positions itself in front of the feeder and } \\
\text { ingests feed }\end{array}$ \\
\hline Drinking & $\begin{array}{l}\text { The bird positions itself in front of the drinker and } \\
\text { drinks }\end{array}$ \\
\hline Standing & $\begin{array}{l}\text { The bird remains standing, and does not perform } \\
\text { any activity }\end{array}$ \\
\hline Threatening & $\begin{array}{l}\text { The bird places itself on front of another bird, with } \\
\text { its neck streched, ruffles its feathers, streches both } \\
\text { wings, and looks at the bird downwards }\end{array}$ \\
\hline Pecking & $\begin{array}{l}\text { One bird aggressively pecks any part of the body } \\
\text { of another bird }\end{array}$ \\
\hline Chasing & One bird chases another bird \\
\hline
\end{tabular}

\section{STATISTICAL ANALYSIS}

Principal Component Analysis (multi-variate analysis) was used to evaluate possible associations among behaviors of birds in the different treatments. Box plots and the test of Kruskal-Wallis at 5\% significance level were used to make comparisons. Pearson's correlation test was applied to verify possible interactions between the environmental parameters and behavioral frequencies. All statistical analyses were performed using the software package MINITAB® 15.1 (Minitab, 2005).
The Influence of Side-Curtain Color on Broiler Chick

Behavior

\section{RESULTS AND DISCUSSION}

Results are discussed in two different sections: rearing environment and chick behavior.

\section{Rearing environment}

Optimal environmental values required by sevenday-old Cobb broilers, according to Cobb management manual (2008), Barnwell \& Wilson (2005), and Globalgap (2007) are shown in Table 2.

Table 2 - Optimal environmental parameter values for seven-day-old broilers.

\begin{tabular}{lc}
\hline Parameter & 7 days \\
\hline $\mathrm{DBT}\left({ }^{\circ} \mathrm{C}\right)$ & $29-30$ \\
\hline $\mathrm{RH}(\%)$ & $30-50$ \\
\hline Vair $\left(\mathrm{ms}^{-1}\right)$ & $<0.5$ \\
\hline $\mathrm{CO}_{2}(\mathrm{ppm})$ & $<3000$ \\
\hline $\mathrm{NH}_{3}(\mathrm{ppm})$ & $<10$ \\
\hline
\end{tabular}

$\mathrm{DBT}-$ dry bulb temperature. $\mathrm{RH}=$ Relative humidity. Vaie $=$ air velocity.

According to the test of Kruskal-Wallis, luminosity was significantly different $(p<0.05)$ among treatments, with the highest luminosity in T3 (68.70 \pm 20.30$)$, followed by T2 $(18.75 \pm 2.87)$ and T1 $(5.13 \pm 0.53)$, as shown in Figure 2.Figure 2 also shows that luminosity in the T3 house was less uniform compared with the other treatments. THI was within the recommended limit only in $\mathrm{T} 2$ house $(73.00 \pm 0.41)$ and was significantly different from the other treatments, which was 77.17 \pm 1.01 for $\mathrm{T} 1$ and $76.83 \pm 0.87$ for $\mathrm{T} 3$, representing a "warning" situation.

There were no differences among treatments $(P>$ $0.05)$ for the other environmental parameters. Relative humidity, air velocity, and CO2 level were within the limits recommended by literature in all treatments (Table 2), although dispersion was wider in terms of air velocity in $\mathrm{T} 2$ and of $\mathrm{CO}_{2}$ level in $\mathrm{T} 1$ (Figure 2). Temperature was maintained within the desired limits in T1 and T3 (Table 2), and T2 presented less variation (Figure 2). Only T2 maintained adequate NH3 levels (Table 2). External temperature was less variable in T2, whereas external relative humidity was less variable in T3 (Figure 2). 
Vercellino R do A, Moura DJ de,

Nääs I de A, Maia AP de A,

Medeiros BBL, Salgado DDA,

Carvalho TRM de

\section{ENVIRONMENTAL PARAMETERS amONg TREATMENTS} 7 DAYS OLD
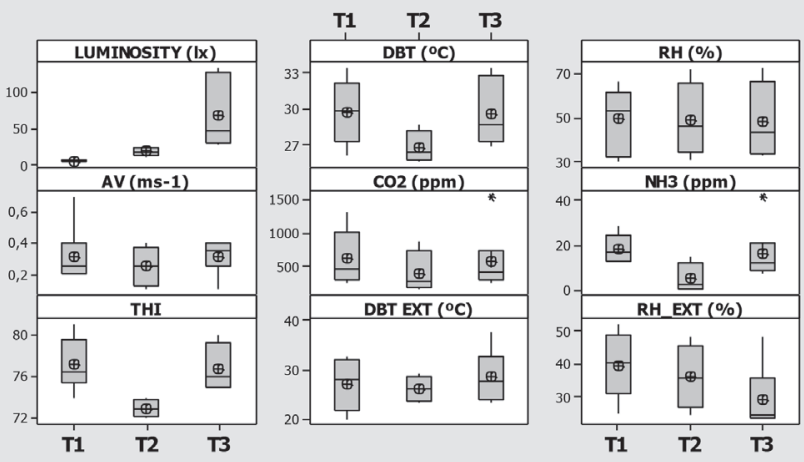

Figure 2 - Box plot of the environmental parameters among treatments when broilers were seven days old.

\section{Behavioral activity}

The results of the multi-variate analysis (Figures 3, 4,5 ) showed that treatments T1 and T2 (Figures 3 and 4 , respectively) explained $60 \%$ of total data variation and treatment T3, 64\% of the variation (Figure 5).Positive correlations of the behaviors lying with $T 1$, running and scratching with $\mathrm{T} 2$, and threatening and chasing with T3.On the other hand, wing stretching and ruffling feathers were negatively correlated with $T 1$, lying with $T 2$, and standing with $T 3$. This indicates that the incidence of behaviors related to physical activity is lower when the environment is darker, as in T1. According to Randall et al. (2000), the capacity of responding to light is a universal aspect of all organisms, and therefore, luminosity is the main stimulus to adjust or to change the cycle activity-rest.

Prescott et al. (2004) and Blatchford et al. (2009) observed that dark environments may have adverse effects on broiler behavior because of vision impairment. However, according to Hester (2005), darkness reduces the incidence of aggressive encounters due to visual impairment, which may explain why the lightest environment (T3) presented a higher frequency of behaviors associated to aggressiveness. It must also be noted that there was greater luminosity variability in T3 compared with T1 and T2 (Figure 2).

Kristensen et al. (2007) evaluated the movement of broilers in environments first with different light intensities ( 5 and $100 \mathrm{~lx}$ ) evenly distributed along one photoperiod, and did not observe any behavioral differences between light intensities. However, when light intensity varied during the photoperiod, birds were less active when was applied compared with those maintained at $1001 x$. Behaviors related to physical
The Influence of Side-Curtain Color on Broiler Chick Behavior

activity are indicators of animal health and welfare and are required for adequate broiler performance (Schwean-Lardner \& Classen, 2010).

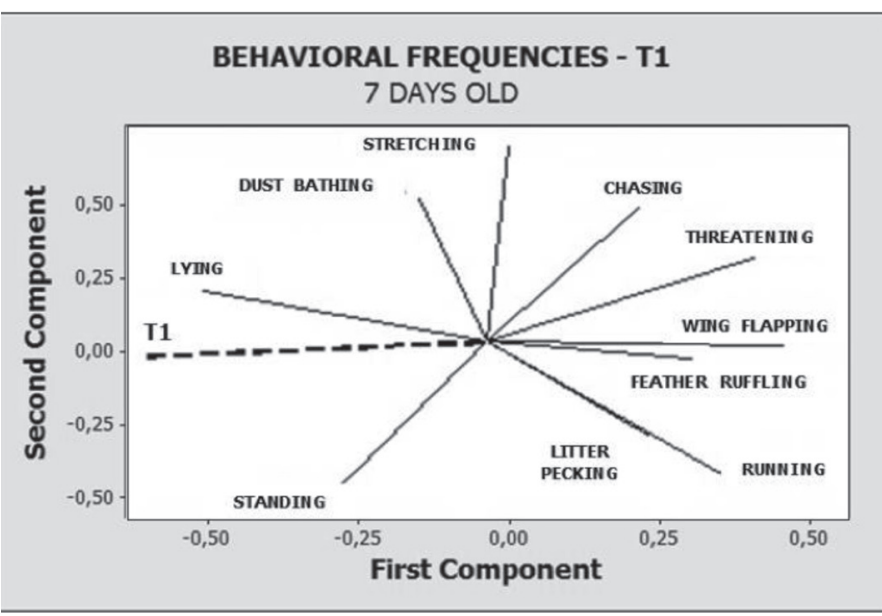

Figure 3 - Graph of the principal components of behavioral frequencies observed in T1 when broilers were seven days old.

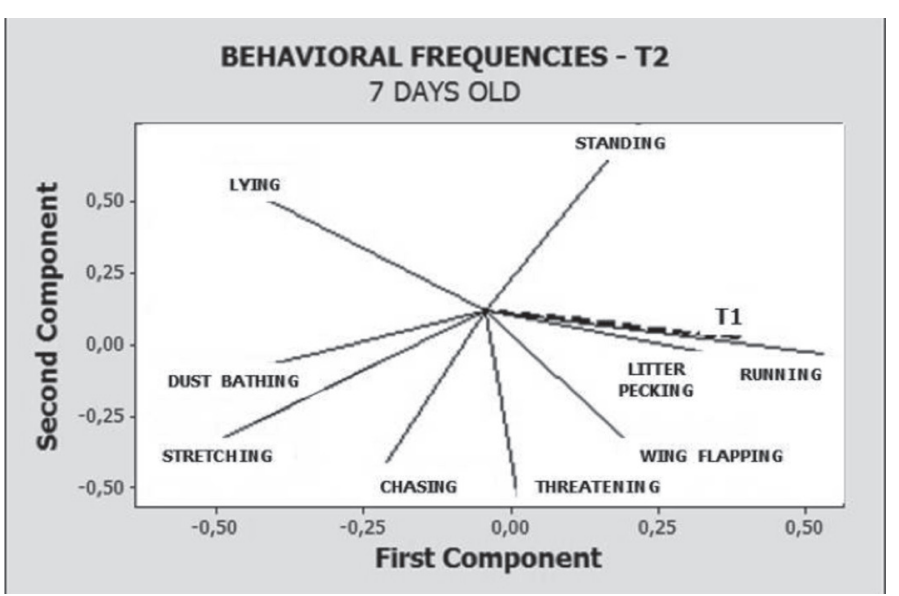

Figure 4 - Graph of the principal components of behavioral frequencies observed in T2 when broilers were seven days old.

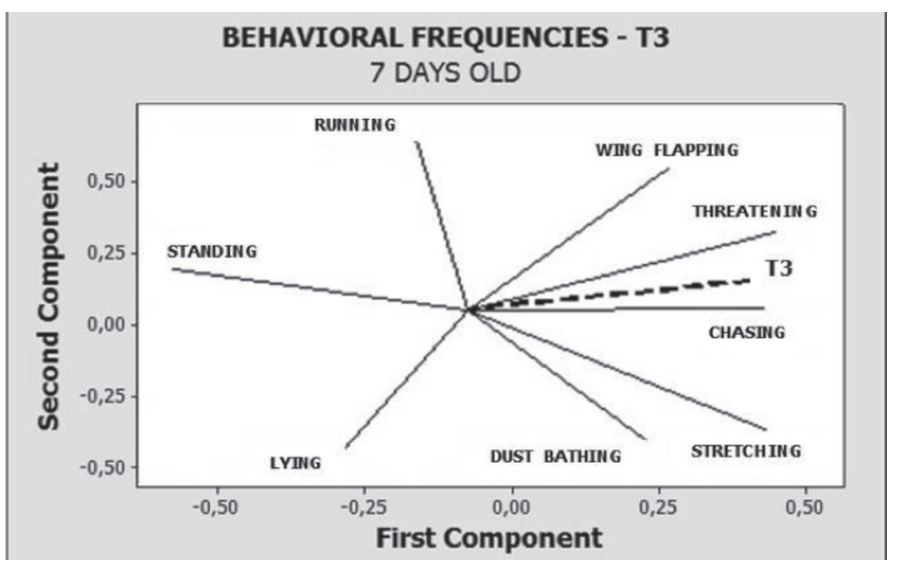

Figure 5 - Graph of the principal components of behavioral frequencies observed in T3 when broilers were seven days old. 
Running, lying, and drinking frequencies differences among treatments were related to luminosity, as determined by the test of Kruskal-Wallis $(p<0.05)$, or to environmental parameters, according to Pearson's correlation test $(p<0.05)$, as shown in Table 3 . The frequencies of the other evaluated behaviors were not different among treatments or were not correlated with environmental variables.

Table 3 - Significant Pearson's correlation test between environmental parameters and behaviors of seven-day-old broilers

\begin{tabular}{|c|c|c|c|c|}
\hline $\begin{array}{l}\text { environmental } \\
\text { parameter }\end{array}$ & & Running & Lying & Drinking \\
\hline \multirow[t]{2}{*}{ IL (Ix) } & Correlation & -0.13 & -0.32 & 0.49 \\
\hline & $P$ value & 0.63 & 0.23 & 0.04 \\
\hline \multirow[t]{2}{*}{ DBT $\left({ }^{\circ} \mathrm{C}\right)$} & Correlation & $-0.72^{\star}$ & 0.62 & 0.30 \\
\hline & $P$ value & 0.00 & 0.01 & 0.25 \\
\hline \multirow[t]{2}{*}{$\mathrm{RH}(\%)$} & Correlation & 0.37 & -0.59 & -0.07 \\
\hline & $P$ value & 0.16 & 0.02 & 0.79 \\
\hline \multirow[t]{2}{*}{ Vair $\left(\mathrm{ms}^{-1}\right)$} & Correlation & -0.49 & 0.18 & -0.09 \\
\hline & $P$ value & 0.05 & 0.51 & 0.74 \\
\hline \multirow[t]{2}{*}{ THI } & Correlation & -0.73 & 0.43 & 0.35 \\
\hline & $P$ value & 0.00 & 0.10 & 0.18 \\
\hline \multirow[t]{2}{*}{ Litter pecking } & Correlation & 0.54 & -0.58 & 0.03 \\
\hline & $P$ value & 0.03 & 0.02 & 0.92 \\
\hline \multirow[t]{2}{*}{ Stretching } & Correlation & -0.55 & 0.09 & -0.14 \\
\hline & $P$ value & 0.03 & 0.74 & 0.62 \\
\hline \multirow[t]{2}{*}{ Lying } & Correlation & -0.58 & - & 0.06 \\
\hline & $P$ value & 0.02 & - & 0.84 \\
\hline \multirow[t]{2}{*}{ Running } & Correlation & - & -0.58 & -0.36 \\
\hline & $P$ value & - & 0.02 & 0.17 \\
\hline
\end{tabular}

* Values in bold show statistically significant results ( $p$ value $<0.05)$. IL = luminosity. $\mathrm{DBT}-$ dry bulb temperature. $\mathrm{RH}=$ Relative humidity. Vair = air velocity.

Running was negatively correlated with temperature, air velocity, and THI (Table 3), and presented positive correlation with scratching the litter and negative correlation with stretching and lying, as expected, because running is an active behavior, opposite to lying and stretching. According to Salgado (2006), stretching occurs before lying, and Campos (2000) observed that broilers reduce their physical activity when there is no thermal comfort. The positive correlation between running and scratching shows that the broilers in the present experiment were able to express their natural behavior, as scratching in an inherent behavior of chickens (Weeks \& Nicol, 2006). Scratching was more frequent in T2, whereas there was no difference among the other treatments (Figure 6 ). The rearing environment in T2 provided thermal comfort, allowing birds to express natural behaviors, such as scratching.

Lying was positively correlated with temperature and negatively correlated with humidity, and presented positive correlation with eating and negative with running and scratching the litter (Table 3 ). Lying was more frequent in T1 than in the other treatments, which were not different from each other (Figure 6). According to Silva et al. (2006), lying indicates stress, because in hot environments, above the thermal neutral zone, broilers reduce their physical activity in order to produce less body heat, remaining lying most of the time (Rutz, 1994).

It should be mentioned that THI in T1 (Figure 2) was outside the optimal range, which would have explained this hypothesis; however, THI was similar between T3 and T1 (Figure 2), and the frequency of lying was lower (Figure 6). Therefore, the best explanation is the low luminosity level. According to Deaton et al. (1976) and Proudfoot \& Sefton (1978), the physical activity of broilers reared in environments with low luminosity is reduced.

Lying was positively associated with eating, and negatively associated with running and scratching the litter, in agreement with Alvino et al. (2009), who found lower physical activity in broilers maintained in darker environments, and with Weeks \& Nicol (2006), who reported that broilers reared confined in poultry houses reduce their litter-scratching behavior because there is high feed availability.

Drinking was positively correlated with luminosity (Table 3). Broiler present higher physical activity in light environments (Alvino et al., 2009) and one of the ways broilers exchange heat is by increasing their water intake (Cordeiro, 2007). Drinking was less frequent in T2 (Figure 6), which temperature was lower, compared with T1 and T3. These results suggest that, although higher luminosity stimulated physical activity, the low temperature allowed better heat exchange, and therefore, there was less need to drink water.

\section{BEHAVIOR FREQUENCIES amONg TREATMENTS} 7 DAYS OLD

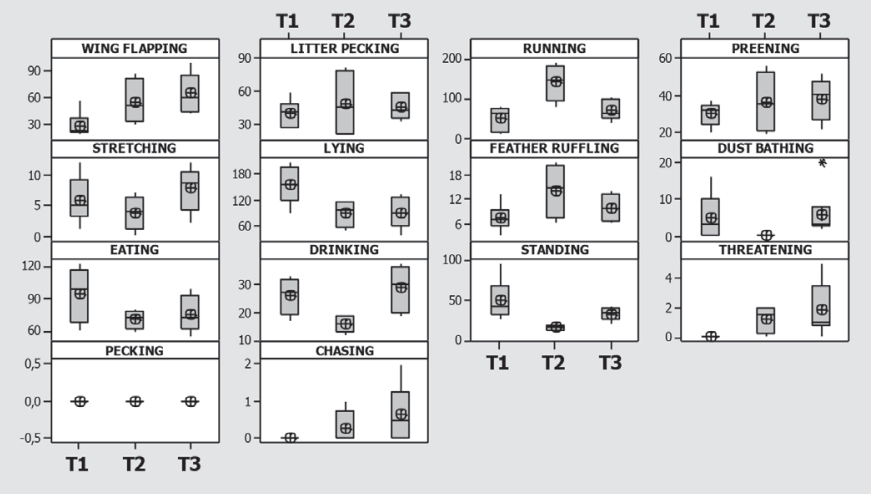

Figure 6 - Box plot of the behavior frequencies among treatments when broilers were seven days old. 


\section{CONCLUSIONS}

Luminosity, together with thermal environment, influenced the behavior of seven-day-old broilers. Therefore, in order to provide good welfare conditions, broilers should be reared in lighter environments, with higher luminosity than those found in the so-called dark houses. The present study showed that "blue houses" have the luminosity range and the thermal environment required to provide adequate welfare for seven-day-old broilers.

\section{REFERENCES}

Altmann J. Observational Study of Behavior: Sampling Methods. Behaviour 1974;49 (3/4):227-67.

Albuquerque VJ, Codenotti TL. Etograma de um grupo de Bugios-pretos, Alouatta caraya (Humboldt, 1812) (Primates, Atelidae) em umhabitat fragmentado. Revista de Etologia 2006;8(2): 97-107.

Alvino GM, Archer GS, Mench JA. Behavioural time budgets of broiler chickens reared in varying light intensities. Applied Animal Behaviour Science 2009;118:54-61.

Barnwellb, Wilson M. Importance of minimum ventilation. Techinical Cobb Focus 2005;1:1-4 [citado em 2011 Out 15]. Disponível em: <http:// www.cobb-vantress.com/publications/documents/focus_tech_1-05. $\mathrm{pdf}>$.

Blatchford RA, Klasing KC, Shivaprasad HL, Wakenell PS, Archer GS, Mench JA. The effect of light intensity on the behavior, eye and leg health, and immune function of broiler chickens. Poultry Science 2009;88:20-8.

Blockhuis HJ, Wiepkema PR. Studies of feather pecking in poultry. The Veterinary Quarterly 1998;20(1):6- 9.

Butcher GD, Nilipour AH. Broiler Management - The first 24 hours. IFAS Extension - University of Florida 2002;1:1-4.

Campos EJ. O comportamento das aves. Revista Brasileira de Ciência Avícola 2000; 2(2).

Cobb - Vantress Cobb - Vantress Brasil. Manual de manejo de frangos de vorte. 66p. [citado em 2010 Maio 2]. Disponível

em:<www.granjaplanalto.com.br/Manual \% 20 Frango \% 20 Corte_20_03_09.pdf>

Cordeiro MB. Análise de imagens na avaliação do comportamento, do bemestar e do desempenho de pintos de corte submetidos a diferentes sistemas de aquecimento [tese].Viçosa (MG): Universidade Federal de Viçosa; 2007

Dawkins MS. The role of behaviour in the assessment of poultry welfare. World's Poultry Science Journal 1999;55(3):295-303.

Deaton JW, Reece FN, Kubena LF, May JD. Effect of varying light intensity on broiler performance. Poultry Science 1976;55:515-19.

Ferrante V, Verga M, Mangiagalli MG, Carenzi C. Behaviour reactions, semen quality and testosterone levels in cocks: genetic implications. Animal Welfare 2001;10(3):269-79.

Globalgap. PY5.4.4. General Regulations: Integrated Farm Assurance 2007;1-7.
Hester PY. Impact of science and management on the welfare of egg laying strains of hens. Poultry Science 2005;84:687-96

Ítavo LCV, Souza SRMBO, Rímoli J, Ítavo CCBFE, Dias AM. Comportamento ingestivo diurno de bovinos em pastejo contínuo e rotacionado. Archivos de Zootecnia 2008;57:43-52.

Köppen W. Das geographisca System der Klimate. Gebr, Borntraeger 1936;1-44.

Kristensen HH, Prescott NB, Perry GC, Ladewig J, Ersboll AK, Overvad KC, Wathes CM. The behavior of broiler chickens in different light sources an illuminances. Applied Animal Behaviour Science 2007;103:75-89.

Lewis PD, Morris TR. Poultry and coloured light. World's Poultry Science Journal 2000;56:189-207.

Lima KAO, Moura DJ, Carvalho TMR, Bueno LGF, Vercellino RA. Ammonia emissions in tunnel-ventilated broiler houses. Brazilian Journal of Poultry Science 2011;13(4):265-70.

Minitab. Version 15.1.0.0; 2005.

Neves DPN, Nääs IA, Vercellino RA, Moura DJ. Do broilers prefer to eat from a certain type of feeder? Brazilian Journal of Poultry Science $2011 ; 12(3): 179-87$

Passos FC, Alho CJR. Importância de diferentes microhabitats no comportamento de forrageio por presas do mico-leão-preto, Leontopithecus chrysopygus (Mikan) (Mammalia, Callitrichidae). Revista Brasileira de Zoologia 2001;18:335-42.

Payne GC. Environmental temperature and egg production. In: HortonSmith $C$, Ambrose EC, editors. The physiology of the domestic fowl. Edinburgh: Oliver and Boyd; 1967. p.235-241.

Pereira DF. Metodologia para estimativa de bem-estar em matrizes de frango de corte utilizando monitoramento digital e construção de modelos de simulação [tese]. Campinas (SP): Faculdade de Engenharia Agrícola, Universidade Estadual de Campinas; 2005.

Pereira DF, Nääs IA, Romanini CEB, Salgado DD, Pereira GOT. Indicadores de bem-estar baseados em reações comportamentais de matrizes pesadas. Revista Engenharia Agrícola 2005;25(2):308-14.

Pereira DF, Salgado DD, Nääs IA, Penha NL, Bighi CA. Efeitos da temperatura do ar, linhagem e período do dia nas freqüências de ocorrências e tempos de expressão comportamental de matrizes pesadas. Revista Engenharia Agrícola 2007;27(3):596-610.

Prescott NB, Wathes CM. Light, poultry and vision. In: Livestock Environment; 2001; Louisville, Kentucky. Estados Unidos. p. 696-702.

Proudfoot FG, Sefton AE. Feed texture and light treatment effects on the performance of chicken broilers. Poultry Science 1978;57:408-16.

Randall D, Burggren W, French K. Fisiologia animal: mecanismos e adaptações. 4 ed. Rio de Janeiro: Guanabara Koogan; 2000.

Rutz F. Aspectos fisiológicos que regulam o conforto térmico em aves. Anais da Conferência APINCO 1994 de Ciência e Tecnologias Avícolas; 1994; São Paulo, São Paulo. Brasil. p. 99-136.

Salgado DD. Modelo estatístico para predição de bem-estar de reprodutoras de frango de corte baseado em dados de ambiente e análise de comportamento [dissertação]. Campina (SP): Faculdade de Engenharia Agrícola , Universidade Estadual de Campinas; 2006

Salgado DD, Nääs IA, Pereira DF, Moura DJ. Modelos estatísticos indicadores de comportamentos associados a bem-estar térmico para matrizes pesadas. Revista de Engenharia Agrícola 2007; 27(3):619-29. 
SCAHAW. Welfare of Chickens Kept for Meat Production (Broilers). Brussels: European Commision; 2000. p. 1-150.

Schwean-Lardner K, Classen H. Lighting for broilers. Scotland: Aviagen; 2010. 39p.

Silva IJO, Barbosa Filho JAD, Silva M, Piedade SMS. Influência do sistema de criação nos parâmetros comportamentais de duas linhagens de poedeiras submetidas a duas condições ambientais. Revista Brasileira de Zootecnia 2006;35(4):1439-46.

Sturkie PD. Fisiologia aviaria. Nova York: Acribia; 1967.

Thom EC. The discomfort index. Weatherwise 1959;12(1):57-60.

Weeks CA, Nicol CJ. Behavioural needs, priorities and preferences of laying hens. World's Poultry Science Journal 2006;62:296-307. 